\title{
The Effect of Hoof Trimming on Milk Yield in Dairy Cattle
}

\author{
Hanifi Erol (Corresponding author) \\ Erciyes University, Faculty of Veterinary Medicine, Department of Surgery, Kayseri, Turkey \\ E-mail: drhaneroll@yahoo.com \\ Gultekin Atalan \\ Erciyes University, Faculty of Veterinary Medicine, Department of Surgery, Kayseri, Turkey \\ E-mail: gatalan@erciyes.edu.tr \\ Muhammed Kaan Yonez \\ Erciyes University, Faculty of Veterinary Medicine, Department of Surgery, Kayseri, Turkey \\ E-mail: kaanyonez@gmail.com \\ Tugba Burcak Ozkocak \\ Farm Veterinarian, Konya, Turkey \\ E-mail: yurekliburcakvet@gmail.com
}

\begin{abstract}
Hoof trimming is necessary for conformation and health of cattle. It is performed to prevent hoof lesions and maintenance the symmetry and shape of claw. At the same time it is a stress factor in dairy cattle. The aim of the study was to investigate the stress effects of hoof trimming on milk yield in healthy dairy cattle. Twenty Simmental dairy cattle were used as material. Functional hoof trimming was performed for all cattle. Dairy milk yield was measured before and after hoof trimming period. There were personal increases and decreases of milk yield recorded in animals. However, these increase and decrease were not statistically significant. As a result of this study hoof trimming is necessary for claw health and prevention for foot diseases. In healthy dairy cattle it causes stress and to decreases in milk yield. On the other hand the hoof trimming time, environmental factors such as flooring system and management style, and the animal related factors such as lactation period and stage, number of milking, breed and age affect the milk yield with hoof trimming positively or negatively.
\end{abstract}

Keywords: Cattle, Dairy, Hoof, Milk, Simmental

DOI: $10.7176 / \mathrm{JSTR} / 5-5-07$

\section{Introduction}

The improving of management increases the milk production in dairy cattle. In contrast, the improvement of management affects the variety systems such as locomotor, metabolic and reproductive. The hooves condition is influenced by nutritional factors, environmental conditions, stress factors and hoof trimming (Ando et al 2008, Izci 2018). Hoof trimming is performed to prevent hoof lesions and to maintenance the symmetry and shape of claw. In this way the equal weight distributions on each cattle foots are ensured. The therapeutic hoof trimming treats foot disorders and significantly effects milk production (Manske et al. 2002, Nishimori et al. 2006, Kibar and Çağlayan 2016).

Regular hoof trimming is the most used way to decrease the hoof diseases incidence. On the other hand hoof trimming can have a negative effect on locomotion score in short period after trimming. However, it has positive effects on decreasing the lameness incidence, reducing the incidence of hoof lesions increasing fat and protein contents of milk (Baranovic et al. 2016). The economic losses in developing countries due to lameness is the third order in dairy cattle industry. The major factor of the losses is reduced of milk yield production due to foot diseases. The researchers continue to investigate the effects of lameness on the milk yield production (Hernandez et al. 2002, Salona et al. 2015, Ozsvari 2017).

Hoof conformation changes depending on growth and wear rates. The growth rate of hooves horn

51 | P a g e

www.iiste.org 
increases after calving in cattle. In contrast, wear rate does not increase in the same period. Therefore, hoof trimming is recommended to dairy cattle twice in a year (Meyer et al. 2007, Livesey and Laven 2007). More than 7 months interval between two hoof trimming increases the risk of hoof diseases in dairy cattle (Mohamadnia and Khaghani 2013).

Hoof trimming is a stress factor in dairy cattle (Ando et al. 2008). Previous studies were focused on the effects of hoof trimming on milk yield in dairy cattle with claw diseases. However, it is not clearly investigated the stress due to hoof trimming on healthy dairy cattle has an effect on milk yield. The aim of the study was to investigate the stress effects of hoof trimming on milk yield in healthy dairy cattle.

\section{Material and Methods}

The study was performed in a commercial dairy farm located at Nevşehir city which in Cappadocia. Twenty Simmental cattle $(3.5 \pm 053$ years, dairy twice milking) were used as material. Lactation period $\left(213 \pm 31.2\right.$ days), lactation stage $\left(2^{\text {th }}\right)$, milk yield in liters $(20.2 \pm 3.17 \mathrm{~L})$ were detected from farm recording system. The cows were fed with same ration program and in same group's animal. Before hoof trimming, all animals were examined or general health status. According to lameness score, the lame cows (score 2, 3, 4 and 5) were not included in the study group. After the cows were fixed in hoof trimming stock then started to functional hoof trimming at standing position. First of all the length of claws were measured (average $7.5 \mathrm{~cm}$ ) and cut. Then sole thickness (average $0.625 \mathrm{~cm}$ ) and heel wall juncture (average $3.75 \mathrm{~cm}$ ) were measured and trimmed. The weight bearing surface between medial and lateral claws were balanced and completed the hoof trimming. After hoof trimming all of the cattle's hooves were controlled about claw diseases. This procedure was performed for all animals. The hooves were trimmed by experienced same person. Milk yield of animals were recorded one day before hoof trimming, at trimming day and during 6 days after hoof trimming period.

Shapiro-Wilk test was used for normality control of data. The data were analyzed by IBM SPSS (version 21.0) statistic program. General Linear model repeated measure ANOVA (Bonferroni corrected) test was made for analyze. Values of $P<0.05$ were considered statistically significant. Results were presented as the mean \pm standart devaition (SD).

\section{Results}

Functional hoof trimming was performed for 20 healthy Simmental dairy cattle. After trimming of claws there were no claw diseases and deformation detected in animals. Before and after hoof trimming milk yield are shown in Table 1. There were personal increases and decreases of milk yield recorded in animals. Especially the milk yield decreases were evident on hoof trimming day. However, these increases and decreases continued for 6 days after hoof trimming and they were not statistically significant.

The group's milk yield average was evaluated in Table 2. Before hoof trimming the average of milk yield was higher until $5^{\text {th }}$ day after hoof trimming. At $5^{\text {th }}$ and $6^{\text {th }}$ days milk yield started to return previous level. However, the changes of milk yields were not statistically different. When all the data were evaluated, there were increases and decreases before and after hoof trimming in the study group, they were not statistically significant. 
Table 1. Milk yield of cows before and after hoof trimming

\begin{tabular}{|c|c|c|c|c|c|c|c|c|c|}
\hline $\begin{array}{l}\text { Animal } \\
\text { Number }\end{array}$ & $\begin{array}{c}\text { BT } \\
\text { (L/day) }\end{array}$ & $\begin{array}{c}\text { TD } \\
\text { (L/day) }\end{array}$ & $\begin{array}{c}\text { AT1D } \\
\text { (L/day) }\end{array}$ & $\begin{array}{c}\text { AT2D } \\
\text { (L/day) }\end{array}$ & $\begin{array}{c}\text { AT3D } \\
\text { (L/day) }\end{array}$ & $\begin{array}{c}\text { AT4D } \\
\text { (L/day) }\end{array}$ & $\begin{array}{c}\text { AT5D } \\
\text { (L/day) }\end{array}$ & $\begin{array}{c}\text { AT6D } \\
\text { (L/day) }\end{array}$ & $\operatorname{Mean} \pm$ SD \\
\hline 1 & 17 & 17.8 & 18.1 & 17.5 & 18.6 & 18.6 & 17.8 & 18 & $17.9 \pm 0.53$ \\
\hline 2 & 22 & 23.7 & 22.3 & 23.7 & 23.3 & 22.3 & 17.2 & 19.7 & $21.7 \pm 2.25$ \\
\hline 3 & 22 & 21.3 & 24.4 & 24.1 & 24.7 & 25 & 24.8 & 23.6 & $23.7 \pm 1.37$ \\
\hline 4 & 14 & 13.8 & 13.3 & 12.6 & 14.9 & 15.9 & 16 & 18.9 & $14.9 \pm 2$ \\
\hline 5 & 21 & 20.4 & 20.5 & 20.9 & 20.9 & 20.2 & 21.4 & 22.9 & $21 \pm 0.84$ \\
\hline 6 & 18 & 17.4 & 18.6 & 17.8 & 16.9 & 18.6 & 19.2 & 19.2 & $18.21 \pm 0.8$ \\
\hline 7 & 23 & 22.9 & 20.7 & 17 & 18.6 & 17.9 & 19.8 & 19.2 & $19.8 \pm 2.19$ \\
\hline 8 & 22 & 21 & 19.9 & 20.6 & 19.7 & 20.6 & 19.7 & 20 & $20.4 \pm 0.79$ \\
\hline 9 & 21 & 20.3 & 20 & 22.9 & 21.9 & 19.4 & 24 & 23.2 & $21.5 \pm 1.67$ \\
\hline 10 & 27 & 26.8 & 25.4 & 28.1 & 23.8 & 19.2 & 26.2 & 26.7 & $25.4 \pm 2.80$ \\
\hline 11 & 24 & 23.5 & 24.5 & 21.9 & 23.2 & 25.2 & 18.7 & 23 & $23.2 \pm 2$ \\
\hline 12 & 16 & 16.7 & 17.1 & 18 & 20.2 & 17.8 & 18.8 & 14.2 & $17.3 \pm 1.81$ \\
\hline 13 & 21 & 20.5 & 17.6 & 23 & 20.8 & 21.6 & 22.3 & 22.6 & $21.1 \pm 1.69$ \\
\hline 14 & 19 & 18.8 & 17.2 & 17.3 & 20.8 & 17.8 & 18.7 & 23 & $19 \pm 1.96$ \\
\hline 15 & 22 & 21.6 & 18.9 & 19.7 & 18.8 & 20.5 & 21.8 & 20.5 & $19.1 \pm 3.60$ \\
\hline 16 & 20 & 19.5 & 20.3 & 18.3 & 10.8 & 20.6 & 20.9 & 22.8 & $20.4 \pm 1.26$ \\
\hline 17 & 15 & 15.5 & 15.9 & 15.4 & 14.7 & 14 & 16.3 & 16.3 & $15.3 \pm 0.8$ \\
\hline 18 & 18 & 16.9 & 17.6 & 18.7 & 17.8 & 14.3 & 16.6 & 16.9 & $17.1 \pm 1.32$ \\
\hline 19 & 20 & 18.3 & 14.2 & 18 & 17 & 17.2 & 19 & 19.3 & $17.8 \pm 1.80$ \\
\hline 20 & 22 & 20.8 & 14.7 & 19.4 & 16.8 & 19.6 & 21.7 & 22.1 & $19.6 \pm 2.66$ \\
\hline
\end{tabular}

BT: before trimming, TD; trimming day, AT1D: after trimming 1.day, AT2D; after trimming 2.day, AT3D; after trimming 3.day, AT4D; after trimming 4.day, AT5D; after trimming 5.day, AT6D; after trimming 6.day.

Table 2. The average of milk yield of group before and after hoof trimming.

\begin{tabular}{|c|c|c|c|c|c|c|c|c|}
\hline $\begin{array}{l}\text { Group } \\
(n=20)\end{array}$ & $\begin{array}{ll}\text { No BT } \\
\text { (L/day) } \\
\text { Mean } \pm \text { SD }\end{array}$ & $\begin{array}{l}\text { TD } \\
\text { (L/day) } \\
\text { Mean } \pm \text { SD }\end{array}$ & $\begin{array}{l}\text { AT1D } \\
\text { (L/day) } \\
\text { Mean } \pm \text { SD }\end{array}$ & $\begin{array}{l}\text { AT2D } \\
\text { (L/day) } \\
\text { Mean } \pm \text { SD }\end{array}$ & $\begin{array}{l}\text { AT3D } \\
\text { (L/day) } \\
\text { Mean } \pm \text { SD }\end{array}$ & $\begin{array}{l}\text { AT4D } \\
\text { (L/day) } \\
\text { Mean } \pm \text { SD }\end{array}$ & $\begin{array}{l}\text { AT5D } \\
\text { (L/day) } \\
\text { Mean } \pm \text { SD }\end{array}$ & $\begin{array}{l}\text { AT6D } \\
\text { (L/day) } \\
\text { Mean } \pm \text { SD }\end{array}$ \\
\hline I & $20.2 \pm 3.17$ & $19.8 \pm 3.09$ & $19 \pm 3.66$ & $19.7 \pm 3.50$ & $19.2 \pm 3.47$ & $19.3 \pm 2.93$ & $20 \pm 2.82$ & $20.6 \pm 2.99$ \\
\hline
\end{tabular}

BT: before trimming, TD; trimming day, AT1D: after trimming 1.day, AT2D; after trimming 2.day, AT3D; after trimming 3.day, AT4D; after trimming 4.day, AT5D; after trimming 5.day, AT6D; after trimming 6.day. $P>0.05$.

\section{Discussion}

Hoof diseases and lameness in dairy cattle are the most common reasons of the reduction in milk production. In recent years, increasing of culture milk cows breeds, changing of the management systems 
in order to increase milk yield are more prominent in our country. Parallel to this statement foot diseases and economic losses increase in our country (Pirci and Atalan 2018, Erol et al. 2019). The relationship between hoof health and milk production is complex. Therefore, investigations of the relationship between hoof health and milk production are still going on. In many studies show that milk production decreased in lame cows which affected due to hoof diseases, and the decrease of milk production rate was 30\% in dairy herds (Olechnowicz and Jasksowski 2010, Akköse and Izci 2017).

In the present study cows were scored for lameness according to Espejo et al. (2006). Non lame cows (score 1) (Espejo et al. 2006) and their milk yield were followed and measured before and after hoof trimming. Functional claw trimming is a repeatable method for maintaining physiological and biomechanical function of cattle digits. At the same time it is a method of the preventing from hoof diseases and lameness in dairy cattle, and it is suggested twice in a year to dairy herds (Pesenhofer et al. 2006, Arican 2017). The hoof trimming is performed twice in a year in this farm. In the study group, it was the first hoof trimming at this lactation period and stage. Daily milk yield average slightly reduced from the day of claw trimming to $5^{\text {th }}$ day after trimming. On $6^{\text {th }}$ day after trimming milk yield average returned to normal value. However, this reduction was not statistically significant. Thonhauser et al. (1994) measured the milk production 7 days before and 22 days after hoof trimming in dairy cattle. They found a $10 \%$ decrease of milk yield during 22 days period and they connected the reduction of milk to trimming stress. In our study we found maximum 5\% milk reduction at $3^{\text {rd }}$ day after claw trimming period. The differences between studies showed that different animal breed, environmental and climate factors, lactation periods and stages, farms' management systems and hoof trimming could be a stress factor on milk yield. All of these factors could affect milk yield and to be tolerated different times. Elongation and shortening of tolerating time can affects economically to dairy farms. Therefore, many researchers focus on the influence of stress factors, foot diseases and their effects on milk yield (Cook et al. 2007, Dippel et al. 2009, Leach et al. 2012). Comfortable walking and standing, equal weight distribution on hooves and correct claw shapes after hoof trimming increase the milk yield, and it has positive effect on prevention of claw diseases (Nishimori et al. 2006, Izci et al. 2018). On contrary, there were no increases detected in milk yield after claw trimming in our study. It decreased at trimming day and after trimming periods. This condition was connected to the hoof trimming stress. However, different number of milking, lactation stage and periods could affect milk production. These factors change the body condition scores of cows. At the same time stress factors increase these factors' influence (Kremer et al. 2007). In our study to eliminate these factors' influence on milk yield, we created our group with similar age, same breed, lactation period and stage. However, we detected the decrease of milk yield and explained it by hoof trimming stress effect.

The flooring system is important for horn claw wear and health. Some researchers investigated the effects of elastic and concrete flooring on claw wear and milk yield (Somers et al. 2005, Kremer et al. 2007). They compared the rubber and concrete flooring systems on claw shapes before and in lactation period, and they found the differences in development of claw traits. Eicher et al. (2013) investigated the rubber flooring effects on production, locomotion, hoof health, immune functions and stress in cattle. They found that the flooring systems of farms could influence the production, locomotion, hoof health and stress. At the same time they said that the rubber flooring system increase the milk yield, hoof health and concrete floor affects these negatively. In the current study, the farm's floor was concrete floor. We thought that the concrete floor contributed to decrease of milk yield after hoof trimming. The concrete floor can compress the corium tissue after hoof trimming because of the thinning claw horn. This condition can cause pain and stress in cattle but not lameness. Thus the average of milk yield can decrease after hoof trimming periods. Furthermore, not to detection of lameness after hoof trimming in animals supported the condition.

As a result of this study hoof trimming is necessary for claw health and prevention for foot diseases. In healthy dairy cattle it causes stress and to decreases in milk yield. On the other hand the hoof trimming time, environmental factors such as flooring system and management style, and the animal related factors such as lactation period and stage, number of milking, breed and age affect the milk yield with hoof trimming positively or negatively. It is recommended that these factors should be considered in future studies.

\section{References}

Akköse, M., İzci, C. (2017). İnek Konforunun Topallıklar Üzerine Etkisi ve Konforun Değerlendirilmesi. Hayvansal Üretim, 58(1): 33-45. 
Ando, T., Annaka, A., Ohtsuka, H., Kohiruimaki, M., Hayashi, T., Hasegawa, Y., Watanebe, D. (2008). Effect of Hoof Trimming before the Dry Period on Productive Performance in Perinatal Dairy Cows. J Vet Med Sci, 70(1): 95-98.

Arıcan, M. (2017). Sığır Cerrahi Atlası, Damla Ofset A.Ş. 1. Baskı, Konya, Türkiye, 319-367.

Baranovic, S., Tancin, V., Mindek, S. (2016). Evaluation of the Hooves of Dairy Cows in Connection with Trimming and Culling. Agric Conspec Sci 81(1): 49-52.

Cook, N.B., Mentink, R.L., Bennett, T.B., Burgi, K. (2007). The effect of heat stress and lameness on time budgets of lactating dairy cows. J Dairy Sci, 90: 1674-1682.

Dippel, S., Dolezal, M., Brenninkmeyer, C., Brinkman, J., March, S., Knierim, U., Winckler, C. (2009). Risk factor lameness in freestall-housed dairy cows across two breeds, farming system and countries. J Dairy Sci, 92: 5476-5486.

Eicher, S.D., Jr, D.C.L., Arthington, J.D., Schutz, M.M. (2013). Effects of rubber flooring during the first 2 lactations on production, locomotion, hoof health, immune functions, and stress. J Dairy Sci, 96: 3639-3651.

Erol, H., Erol, M., Alkan, F. (2019). Konya yöresinde sağmal süt sığırı (Montofon) işletmesinde karşılaşılan tırnak lezyonlarının değerlendirilmesi. Eurasian J Vet Sci, 35 (1): 24-28.

Espejo, L.A., Endres, M.I., Salfer, J.A. (2006). Prevalence of lameness in high producing holstein cows housed in freestall barns in Minnesota. J Dairy Sci, 89: 3052-3085.

Hernandez, J, Shearer, J.K, Webb, D.W. (2002). Effect of lameness on milk yield in dairy cows. J Am Vet Med Assoc, 220(5):640-644.

Izci, C., Erol, M., Gökşahin, E. (2018). Boynuz ve canlı tırnak lezyonu (BCTL) bulunan süt sığırlarında ökçe yastığının ultrasonografik olarak değerlendirilmesi. Eurasian J Vet Sci, 34(2): $109-116$

Izci, C. (2018). Sığırlarda ayak hastalıkları ve topallık Kontrolü. Selçuk Üniversitesi Basım evi, 1. bask1, Konya, Türkiye, 1-83, 196-271.

Kremer, P.V., Nueske, S., Scholz, A.M., Foerster, M. (2007). Comparison of Claw Health and Milk Yield in Dairy Cows on Elastic or Concrete Flooring. J Dairy Sci, 90:4603-4611.

Kibar, M., Çağlayan, T. (2016). Effect of Hoof Trimming on Milk Yield in Dairy Cows with Foot Disease. Acta Scientiae Veterinariae, 44, 1370: 1-7.

Leach, K.A., Tisdall, D.A., Bell, N.J., Main, D.C.J., Green, L.E. (2012). The effects of early treatment for hindlimb lameness in dairy cows on four commercial UK farms. The Veterinary Journal, 193: $626-632$

Livesey, C.T, Laven, R.A. (2007). Effects of housing and intake of methionine on the growth and wear of hoof horn and the conformation of the hooves of first-lactation Holstein heifers. Vet Rec, 160(14): 470-476.

Manske, T., Hultgren, J., Begsten C. (2002). The effect of claw trimming on the hoof health of Swedish dairy cattle. Preventive Veterinary Medicine, 54(2): 113-129.

Meyer, S.W., Weishaupt, M.A., Nuss, K.A. (2007). Gait pattern of heifers before and after claw trimming: A high-speed cinematographic study on a treadmill. J Dairy Sci, 90(2): 670-676.

Mohamadnia, A., Khaghani, A. (2013). Evaluation of hooves' morphometric parameters in different hoof trimming times in dairy cows. Veterinary Research Forum, 4(4):245-249. 
Nishimori, K., Okada, K., Ikuta, K., Aoki, O., Sakai, T., Yasuda, J. (2006). The effects of one time trimming on blood biochemical composition, milk yield, and milk composition in dairy cows. JVMS, 68(3): 267-270.

Olechnowicz, J., Jaskowski, J.M. (2010). Incidence and prevalence of lameness and their relationship to milk yield in high-yielding cows. Medycyna Wet, 66(12): 818-821.

Ozsvari L. (2017). Economic cost of lameness in dairy cattle herds. J Dairy Vet Anim Res, 6(2): 283289.

Pesenhofer, G., Palme, R., Pesenhofer, R.M., Kofler, J. (2006). Comparison of two methods of fixation during functional claw trimming - walk-in crush versus tilt table - in dairy cows using faecal cortisol metabolite concentrations and daily milk yield as parameters. Vet. Med. Austria / Wien. Tierärztl. Mschr, 93:288-294.

Pirci, B., Atalan, G. (2018). Kayseri Develi Tarımsal Kalkınma Kooperatifi Süt Sığırı Çiftliğinde Bulunan Sığır Tırnaklarının Muayenesi ve Problemli Tırnakların Sağaltımı. Erciyes Üni Vet Fak Derg, 15(3): 222-229.

Solano, L., Barkema, H.W., Pajor, E.A., Mason, S., LeBlanc, S.J., Zaffino Heyerhoff, J.C., Nash, C.G., Haley, D.B., Vasseur, E., Pellerin, D., Rushen, J., dePassille A.M., Orsel, K. (2015). Prevalance of lameness and associated risk factors in Canadian Holstein-Friesian cows housed in freestall barns. J Dairy Sci 98(10): 6978-6991.

Somers, J. G. C. J., W. G. P. Schouten, K. Frankena, E. N. Noordhuizen-Stassen, J. H. M. Metz. (2005). Development of claw traits and claw lesions in dairy cows kept on different floor systems. J Dairy Sci, 88:110-120.

Thonhauser, M.M., Stanek, Ch., Schoder, G. (1994): Zur Beeinflussung von Milchmenge, Zellzahl und bakteriologischem Befund der Milchproben durch eine nach der Schmiedemethode durchgeführten Klauenkorrektur beim Milchrind. Wien. Tierärztl. Mschr. 81, 66-72. 